\title{
Cyclooxygenase-2 (COX-2) inhibitors: future therapeutic strategies for epilepsy management
}

\author{
Chitra Rawat ${ }^{1,2}$, Samiksha Kukal ${ }^{1,2}$, Ujjwal Ranjan Dahiya ${ }^{1,2}$ and Ritushree Kukreti ${ }^{1,2^{*}}$
}

\begin{abstract}
Epilepsy, a common multifactorial neurological disease, affects about 69 million people worldwide constituting nearly $1 \%$ of the world population. Despite decades of extensive research on understanding its underlying mechanism and developing the pharmacological treatment, very little is known about the biological alterations leading to epileptogenesis. Due to this gap, the currently available antiepileptic drug therapy is symptomatic in nature and is ineffective in 30\% of the cases. Mounting evidences revealed the pathophysiological role of neuroinflammation in epilepsy which has shifted the focus of epilepsy researchers towards the development of neuroinflammation-targeted therapeutics for epilepsy management. Markedly increased expression of key inflammatory mediators in the brain and blood-brain barrier may affect neuronal function and excitability and thus may increase seizure susceptibility in preclinical and clinical settings. Cyclooxygenase-2 (COX-2), an enzyme synthesizing the proinflammatory mediators, prostaglandins, has widely been reported to be induced during seizures and is considered to be a potential neurotherapeutic target for epilepsy management. However, the efficacy of such therapy involving COX-2 inhibition depends on various factors viz., therapeutic dose, time of administration, treatment duration, and selectivity of COX-2 inhibitors. This article reviews the preclinical and clinical evidences supporting the role of COX-2 in seizure-associated neuroinflammation in epilepsy and the potential clinical use of COX-2 inhibitors as a future strategy for epilepsy treatment.
\end{abstract}

Keywords: Cyclooxygenase-2 (COX-2), Seizure, Epilepsy, Inflammation, Blood-brain barrier (BBB), Anticonvulsant, Adjunctive

\section{Background}

Epilepsy, a common neurological disorder, is characterized by (1) at least two unprovoked seizures occurring > $24 \mathrm{~h}$ apart, (2) one unprovoked seizure and a probability of further seizures similar to the general recurrence risk (at least 60\%) after two unprovoked seizures, occurring over the next 10 years, or (3) diagnosis of an epilepsy syndrome [1]. The underlying pathophysiology behind the disease progression is still unknown, and therefore, the only available remedy is to control the frequency of seizures using the symptomatic treatment, antiepileptic drugs (AEDs). However, nearly $30 \%$ of the patients do

\footnotetext{
*Correspondence: ritus@igib.in

${ }^{1}$ Genomics and Molecular Medicine Unit, Institute of Genomics and Integrative Biology (IGIB), Council of Scientific and Industrial Research (CSIR), Mall Road, Delhi 110007, India

${ }^{2}$ Academy of Scientific and Innovative Research (AcSIR), Council of Scientific and Industrial Research (CSIR), Delhi, India
}

not respond to the available AEDs [2], emphasizing the need to develop better effective therapies which can target epileptogenesis.

Investigations to elucidate the mechanisms involved in epileptogenesis provided strong evidences on the crucial role of inflammation as the cause as well as consequence of seizure and epilepsy development [3]. In this regard, inflammatory molecules such as cytokines, chemokines, and prostaglandins (PGs) are often observed to be released by the brain and brain capillary endothelial cells affecting neuronal function and excitability in preclinical and clinical set-ups [4]. Blocking the undesired inflammatory signaling using anti-inflammatory molecules may provide novel strategies to treat epilepsy [5]. The inflammatory molecules might, therefore, serve as therapeutic targets to develop better effective medications for epilepsy management.

(c) The Author(s). 2019 Open Access This article is distributed under the terms of the Creative Commons Attribution 4.0 International License (http://creativecommons.org/licenses/by/4.0/), which permits unrestricted use, distribution, and reproduction in any medium, provided you give appropriate credit to the original author(s) and the source, provide a link to the Creative Commons license, and indicate if changes were made. The Creative Commons Public Domain Dedication waiver (http://creativecommons.org/publicdomain/zero/1.0/) applies to the data made available in this article, unless otherwise stated. 
Over the past two decades, cyclooxygenase-2 (COX-2), being the central link to various inflammatory processes, has received much attention due to its involvement in seizure generation and epilepsy development. COX-2 has been reported to be upregulated in different cells within the brain following seizure induction leading to increased production of proinflammatory mediators, PGs, which further aggravates seizure severity [6]. Besides, in vivo evidences suggest that COX-2 induction following seizure may upregulate the multidrug efflux transporter P-glycoprotein (P-gp) at the blood-brain barrier (BBB) causing reduced delivery of administered AEDs to the brain target site, thus leading to poor efficacy [7]. Such studies proposed that inhibition of COX-2, genetic or pharmacological, might reduce seizure severity and pharmacoresistance to AEDs and thus could be exploited as a future strategy for epilepsy treatment.

In this article, we review the preclinical and clinical evidences supporting the role of COX-2 in seizureassociated neuroinflammation in epilepsy and its regulatory effect governing patient's response to AEDs. This review also addresses the potential therapeutic use of COX-2 inhibitors as (1) anticonvulsants for epilepsy management or (2) adjunctives to AED therapy to overcome pharmacoresistance.

\section{Inflammation in epilepsy}

Neuroinflammation comprises activation of microglia, astrocytes, brain capillary endothelial cells, and circulating peripheral immune cells along with the production of inflammatory mediators, initiated in response to a variety of stimulus such as traumatic brain injury, brain infection, and autoimmunity. Evidences revealing the altered expression of different cytokines, chemokines, and other immune-related molecules in epilepsy indicated inflammation as a crucial factor contributing in its pathogenesis. Increased glial cellular expression of a cytokine IL- $1 \alpha$ was observed in patients with drug-resistant temporal lobe epilepsy (DRTLE) with complex partial seizures [8]. An equally potent inflammatory cytokine $I L 1 B$ was also found to be associated with epilepsy when a polymorphism in that gene responsible for increasing the production of IL- $1 \beta$ was detected in patients with temporal lobe epilepsy (TLE) [9]. Besides, cerebrospinal fluid (CSF) as well as serum samples from patients experiencing seizures exhibited increased levels of different cytokines such as IL-1 $1 \beta$, IL-6, IL-1Ra, and IFN $\gamma$, substantiating the role of such cytokines in seizure sustenance [10-13]. A recent follow-up study compared central and peripheral levels of IL-1 $\beta$ and IL-6 in sera of drug-resistant patients before surgical treatment and 1 year after surgery when most patients were either seizure-free or had reduced seizures [14]. The respective levels were found to decrease in the absence of seizures after surgical treatment indicating seizure-induced inflammation. Gene expression profiling of surgically removed hippocampal tissue from patients with TLE revealed upregulation of several chemokines, CCL2, CCL3, and CCL4 along with the chemokine receptor, CXCR4 [15]. The chemokine ligand CX3CL1 was also observed to be upregulated in the hippocampus and the adjacent cortex of epileptic rats as well as in temporal neocortex of patients with TLE [16]. CX3CL1 was further reported to be elevated in the CSF and serum of the same patients compared to the non-epileptic group. Expression of another C-X-C chemokine motif ligand CXCL13 and its receptor CXCR5 were also altered in brain tissues of patients with DRTLE [17]. These alterations were associated with changes in the molecules regulating the cytokines. Severe neuronal loss and persistent overexpression of NFkB-p65, a key regulator of acute inflammatory reactions, was noticed in reactive astrocytes in human medial TLE with hippocampal sclerosis (HS) [18]. The findings were strengthened by Das et al. who revealed an upregulation of NF-kB-p65 along with COX-2 enzyme and TGF- $\beta$ in the hippocampal region as the key molecular events associated with histopathological changes observed in DRTLE [19]. Such clinical evidences and their similarities with the findings of rodent studies promoted the use of in vivo animal models to determine the putative mechanism underlying the shared link between inflammation and seizures.

Accumulating evidences in in vivo experimental models suggested the role of inflammation as either the cause or the consequence of epilepsy contributing to its pathophysiology [3]. Findings from the studies performed in rodent epilepsy models showed activation of hippocampal astrocytes and glial cells along with the elevation of inflammatory mediators in the hippocampus. A transient time-dependent increase in expression of important inflammatory cytokines IL-1 $\beta$, IL-6, and TNF $\alpha$ was observed in the hippocampus of electrically induced limbic status epilepticus (SE) rat model [20]. SE induction in mouse altered the expression of chemokine receptors, CCR3 and CCR2A, and their ligands in the brain and thereby may weaken the neuroprotective mechanisms [21]. Furthermore, microarray analysis of different brain regions of rat model of TLE during epileptogenesis indicated alterations in inflammatory molecules such as interleukins in the acute, latent, and chronic phase of epilepsy [22]. Besides the cytokines, induction of the proinflammatory enzyme COX-2 was observed in hippocampal and neocortical neurons upon hippocampal kindling in rats, suggesting COX-2 induction to be a key signaling event in epileptogenesis [23]. A remarkable rise in the production of COX enzyme products, i.e., PGs, was observed along with the increased COX-2 expression, following seizure induction in rodents $[6,24]$. Such studies illustrate inflammation as a consequence of seizure induction and epilepsy.

Systemic administration of lipopolysaccharide (LPS), an inducer of inflammation, prior to SE induction increased hippocampal vulnerability to seizure-induced neuronal injury in immature rats, suggesting the involvement of 
inflammation in seizure etiology [25]. LPS administration in immature rats also increased kindling progression indicating LPS-induced inflammation to enhance epileptogenesis [26]. Administration of high doses of IL-1 $\beta$, a pyrogenic proinflammatory cytokine, induced febrile seizures in only IL-1 $\beta$ receptor-expressing mice whereas IL-1 $\beta$ receptor-deficient mice were resistant to seizure generation [27]. Brain transcriptome profiling in Wistar rats after epileptogenic treatment revealed TGF- $\beta$ signaling as a novel inflammatory cascade involved in influencing the generation of epileptiform activity [28]. Endogenous nitric oxide (NO), another proinflammatory mediator, increased seizure activity in mice brain slices and reported as a key promoting factor for initiation of seizure-like events [29]. Similarly, intrahippocampal injection of HMGB1, a cytokine-like proinflammatory molecule, increased seizure frequency in epileptic rats [30]. However, the effect abrogated in case of TLR-4 mutant mice, recognizing the involvement of HMGB1-TLR4 inflammatory axis in generating seizures. Furthermore, expression of different inflammatory mediators TLR4, ATF3 , and IL- 8 in the epileptic brain tissue of patients with mesial TLE correlated with their seizure frequency, supporting the etiologic role of inflammation in seizure generation [31]. Therefore, inflammation plays a reciprocal role in epilepsy, i.e., an outcome of seizure activity as well as a contributing factor in the disease development.

\section{Inflammation: a potential therapeutic target}

Current anticonvulsive therapy primarily consists of AEDs which only control the frequency of seizures and hence considered symptomatic. AEDs function by exerting a number of concurrent mechanisms involving both the excitatory and inhibitory synapses. Common modes of action include targeting ion channels and neuroreceptors embedded in the cell membrane to regulate neuronal excitability. Most of the AEDs such as phenytoin, carbamazepine, valproate, and topiramate act as sodium channel blockers by stabilizing the inactivated state of these channels, thus preventing the neuronal depolarization and excitability [32]. On the contrary, activation of potassium channels by retigabine causes a generalized reduction in neuronal excitability by driving the membrane potential to a hyperpolarized state [33]. Gabapentin and pregabalin act on presynaptic calcium channels and blocks calcium-mediated release of neurotransmitter across the synapse, preventing the synaptic conduction [34]. Simultaneously, inhibition of glutamate receptor by topiramate prevents the effect of the excitatory neurotransmitter, glutamate, while agonists of the inhibitory neurotransmitter, $\gamma$ aminobutyric acid (GABA), such as benzodiazepines activate GABA receptor preventing generation of neuronal action potential. Valproate and vigabatrin increase GABA turnover by blocking its degradation [32, 33].
Levetiracetam works by binding to the synaptic vesicle protein, SV2A, causing a reduction in the vesicular release of neurotransmitter, thus differing in its mechanism from other AEDs [34].

Despite the availability of a wide spectrum of AEDs with diverse pharmacological targets, 30\% of patients experience multidrug resistance in epilepsy [35]. Various hypotheses have been proposed to address the molecular mechanism behind this drug resistance. Drug target hypothesis suggested that resistance to AEDs is caused by genetic or acquired alterations at their target sites (ion channels or neuroreceptors associated with neuronal excitability) affecting the pharmacodynamics of the drug [36]. Genetic polymorphisms in the target genes such as SCN1A and GABRA1 have been observed to be associated with AED dose requirements or AED resistance [3740]. Transporter hypothesis proposed that increased expression of ATP-binding cassette $(\mathrm{ABC})$ efflux transporters at the $\mathrm{BBB}$ interferes with the pharmacokinetics of the AEDs leading to their decreased concentration at the target site [41]. Brain endothelial cells and other brain cells of patients with refractory epilepsy have been reported to have increased expression of $\mathrm{ABC}$ transporters compared to healthy individuals [42-44]. A third recent hypothesis known as intrinsic severity hypothesis correlated AED resistance with the severity of the disease [45]. The higher the seizure frequency, the more difficult it is to treat with the available AEDs [46, 47]. Another recent hypothesis called the methylation hypothesis proposed that seizures can mediate epigenetic modifications that result in persistent genomic methylation, histone density, and posttranslational modifications, as well as noncoding RNA-based changes leading to pharmacoresistance in epilepsy [48].

In view of the above hypotheses, till date, nothing conclusive has been gained to address pharmacoresistance in epilepsy, suggesting a gap in the current pharmacological research which often overlooks inflammation as a primary therapeutic target in managing epilepsy. Findings of studies examining whether the currently available AEDs possess anti-inflammatory action are quite debatable. Levetiracetam displayed anti-inflammatory property by reducing immunoreactivity of astrocytic and glial IL- $1 \beta$ system in epileptic rat hippocampus; on the other hand, valproate was unable to show such effects [49]. However, whether the drug has primary anti-inflammatory properties or secondary to reduced seizure activity is still a question. Pre-administration of vinpocetine and carbamazepine before LPS also reduced the brain mRNA levels of IL- $1 \beta$ and TNF- $\alpha$ in rats while valproate again showed neutral behavior [50]. The same study also showed complete prevention of seizure activity along with decreased IL-1 $\beta$ and TNF- $\alpha$ mRNA levels in the groups pre-administered with the two AEDs before the pro-convulsive drug, 4-aminopyridine, suggesting that the antiinflammatory action of these drugs might be achieved primary to reduced epileptic activity. Further investigation 
on such evidences is required to better understand the mechanism of anticonvulsive agents. Contrary to these findings, Verotti et al. observed that both carbamazepine and valproate induced inflammation by increasing interleukin and chemokine levels in children with epilepsy on 1 year of monotherapy [51]. The conflicting findings on the effect of these AEDs on inflammation hint towards the need of a better efficacious anti-inflammatory treatment to manage epilepsy.

Given the indispensable role of inflammation in epilepsy pathogenesis, inflammatory molecules may be considered as important therapeutic targets for epilepsy management; however, evidence on the efficacy of such therapy is limited. Vezzani et al. demonstrated powerful anticonvulsant action of IL-1Ra, an endogenous IL-1 receptor antagonist, by blocking the proinflammatory action of IL-1 $\beta$ in mice [52]. Another study observed a delay in onset of seizure and decrease in its duration when the administered caspase- 1 inhibitor reduced IL-1 $\beta$ levels in SE rats [53]. The similar finding was observed in a more recent study, where epigenetic impairment of IL-1 $\beta /$ TLR4 pathway reduced seizure frequency by approximately $50 \%$ while the widely prescribed AED, carbamazepine, was ineffective, again representing the anti-inflammatory therapy as a pivotal strategy to manage drug-resistant epilepsy [54]. Selective PG EP2 receptor antagonist also reduced SE-induced neuronal injury by preventing COX-2 upregulation in rats [55]. Supporting this, administration of rofecoxib, a COX-2 inhibitor, potentiates the anticonvulsant activity of subeffective dose of tiagabine against pentylenetetrazol (PTZ)-induced convulsions in mice [56]. Therefore, inhibition of such inflammatory molecules may serve as an effective treatment strategy for drug-resistant epilepsy.

Inflammation is a complex biological process involving several proinflammatory as well as anti-inflammatory mechanisms. While application of a polypharmaceutical approach may have unintended consequences through drug-drug interactions [57], targeting an inflammatory cascade which involves both pro- and anti-inflammatory molecules may be exactly what would produce the desired effects by reducing inflammation, provided the anti-inflammatory mechanisms remain intact. Therefore, identification of such cascade involving different inflammatory processes is essential to produce broad-spectrum efficacious treatment. Notably, most of the published findings on crosstalk or signaling pathways of inflammation converge at the common proinflammatory gene, COX-2 (Fig. 1). COX-2 is rapidly induced after a proinflammatory event with a subsequent release of PGs, potent mediators of inflammatory responses. IL- $1 \beta$ released by activated microglia during inflammation of the central nervous system (CNS) was shown to induce COX-2 and biosynthesis of its proinflammatory product, $\mathrm{PGE}_{2}$, in mice astrocytes
[58] and in human neuroblastoma cells [59]. Increased levels of HMGB1 found within inflamed synovium of rheumatoid arthritis patients potentiate IL- $1 \beta$ to stimulate COX-2 and prostanoid synthesis [60]. Similarly, the proinflammatory cytokine, TNF $\alpha$, also induces COX-2 expression and $\mathrm{PGE}_{2}$ release resulting in enhanced vascular permeability and cytoskeletal changes in brain capillary endothelial cells [61]. The signaling pathways connecting such cytokines to COX-2 expression may involve regulatory kinases such as SPK, TK, PKC, NF- $\mathrm{B}$, ERK, and MAPK [58, 62-64]. The chemokine, CXCL1, induced COX-2 via ERK, thus mediating astroglialneuronal interaction to enhance sensitization towards neuropathic pain [65]. More recently, activation of COX-2 and PG production by TGF- $\beta 1$ via ALK5/SMAD and MEK/ ERK pathway in dental pulp cells have been demonstrated to be an early event in tissue inflammation and regeneration [66]. Besides the cytokines, TLR4 was also found to regulate COX-2 in TLR4-positive human intestinal epithelial cells which expressed higher COX-2 levels upon LPS exposure compared to TLR4-negative cells [67]. Simultaneously, in vivo induction of colitis showed increased COX-2 expression in wild-type mice compared to TLR4-deficient mice. Besides, the anti-inflammatory cascades involving IL-10, IL4 , and IL-1Ra have also been shown to regulate COX-2 in different cells [68-70]. Moreover, administration of COX-2 inhibitors, ibuprofen and celecoxib, following traumatic brain injury in rats showed no significant difference in brain IL-10 indicating anti-inflammatory mechanisms to remain intact in presence of COX-2 inhibitors [71]. COX-2, therefore, serves as a downstream molecule to several inflammatory processes. In addition, change in the COX-2 activity itself has also been reported to alter the pro-inflammatory pathways. Treatment with a selective COX-2 inhibitor, SC58125 , reduced synovial inflammation by reducing local and systemic IL-6 levels, thus reversing paw edema in adjuvantinduced arthritis rat model showing regulation of IL-6 by COX-2-derived PGs [72]. Consistent with this, increased $\mathrm{PGE}_{2}$ production and IL-6 levels in IL-1 $\beta$-stimulated human fibroblast-like synoviocytes from patients with disk displacement were reversed on in vitro treatment with COX-2 inhibitors, celecoxib, and indomethacin [73]. Indomethacin also reduced IL- $1 \beta$ and TNF- $\alpha$ expression in hippocampus of pilocarpine-induced SE rat model [74] demonstrating a regulatory effect of COX-2 on these inflammatory molecules. COX-2, therefore, acts as a central signaling molecule for various inflammatory processes and could be explored as a potential therapeutic target for the management of numerous diseases including epilepsy.

\section{Cyclooxygenases (COX)}

Prostaglandin-endoperoxide synthases (PTGS), also known as COX, are enzymes which synthesize prostanoids involving PGs and thromboxane from their substrate arachidonic acid (AA). Mammalian COX 


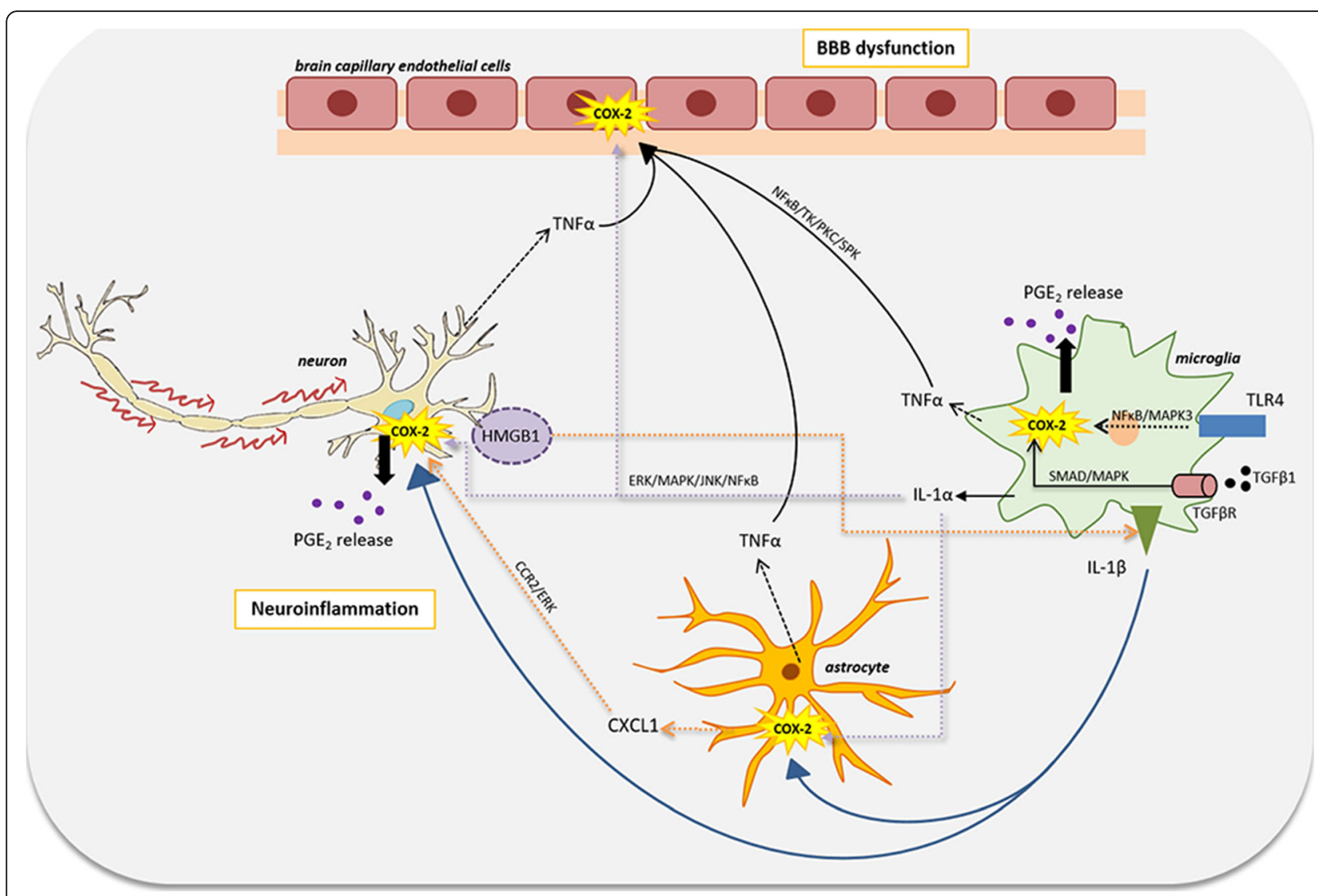

Fig. 1 Regulatory pathways linking COX-2 with pro-inflammatory cascades in the brain: epilepsy induces neuroinflammation as well as peripheral inflammation which further reciprocate by aggravating the disease. Several pro-inflammatory processes involving the cytokines, chemokines, tolllike receptors, etc. often cause induction of the enzyme, COX-2, which increases the production of the lipid mediators, prostaglandins (PGs), majorly PGE . COX-2 induction in the brain capillary endothelial cells can cause blood-brain barrier (BBB) dysfunctioning leading to enhanced efflux of the administered AEDs and therefore, may lower their delivery to brain resulting in reduced AED efficacy. Activation of microglia and astrocytes may also result in COX-2 induction contributing to the build-up of $\mathrm{PGE}_{2}$ and other inflammatory mediators in themselves as well as neurons, thereby causing neuroinflammation

enzyme group consists of two widely studied and wellunderstood oxygenases, COX-1 and COX-2, responsible for the synthesis of the proinflammatory mediators, PGs. With the help of mutagenesis, X-ray crystallography, and kinetic studies, their structure and mechanism of action are well established [75]. The two isoforms COX-1 and COX-2 catalyzing the synthesis of inflammatory molecules are almost similar in weight with $60-65 \%$ sequence similarity; however, they differ in their localization and expression. While COX-1 is constitutively expressed in nearly all tissues, COX-2 is an inducible enzyme primarily localized to immune cells such as macrophages and leucocytes and upregulated in pathological conditions [76]. Further, COX-1 is believed to be responsible for homeostatic PG production whereas COX-2 produces PGs which are generally pathophysiological in nature [77]. Exposure to endotoxins, cytokines, and mitogens induces COX-2 in different cell types such as chondrocytes and macrophages, suggesting the involvement of COX-2 in inflammatory responses. In this regard, administration of COX-2 inhibitory drugs is considered as the treatment to suppress inflammation in various acute and chronic conditions. The last two decades have seen tremendous research on the role of COX-2 in various neuroinflammatory diseases including epilepsy and its applicability as a neurotherapeutic target.

\section{COX-2-mediated neuroinflammation in epilepsy}

COX-2-mediated neuroinflammation is a subject of broad and current interest in basic epilepsy research. Yamagata et al., for the first time, demonstrated immediate induction of COX-2 mRNA and protein in rat hippocampus and cerebral cortex following a maximal electroconvulsive seizure [78]. They also demonstrated this seizure-mediated COX-2 induction to be regulated by $\mathrm{N}$-methyl-D-aspartate (NMDA) receptor-dependent synaptic activity. They further proposed that COX-2 induction during seizure leads to the activation 
of PG signaling pathway, consequently triggering secondary damage to the brain and amplifying disease severity. Thereafter, several studies replicated the findings in other rat brain tissues, striatum, brain stem and cerebellum, besides hippocampus and cerebral cortex in kainic acid (KA) as well as electroconvulsive shock-induced seizures, suggesting delayed neuronal damage of an interconnected neuronal network during COX-2 activation [79-81]. COX-2 induction, in turn, facilitated recurrence of hippocampal seizures in a mouse model of kindling by synthesizing more $\mathrm{PGE}_{2}$ [6]. Production of $\mathrm{PGE}_{2}$, the major product of $\mathrm{COX}-2$, was observed to be increased along with COX-2 induction following seizures, stimulating neuronal loss in rodent models of epilepsy [82, 83]. Furthermore, combining $\mathrm{PGE}_{2}$ with subconvulsant dose of PTZ caused seizures whereas administration of $\mathrm{PGE}_{2}$ antibodies attenuated PTZ-induced seizures in rats, supporting a key role of $\mathrm{PGE}_{2}$ production in triggering seizure and maintaining its threshold [84]. $\mathrm{PGE}_{2}$ binds to $\mathrm{G}$ protein-coupled receptors (GPCRs), namely EP1, EP2, EP3, and EP4, with highest affinity for the EP1 receptor. Activation of EP receptors results in increased calcium ion influx which in turn enhances glutamate release presynaptically $[85,86]$. Genetic ablation or pharmacological inhibition of EP1 receptor in mice did not affect the seizure threshold but prevented the likelihood of SE and aggravation of seizure severity, indicating the involvement of EP1 receptor in seizure exacerbation $[87,88]$. Unlike EP1, studies on the involvement of EP2 receptor in neuroprotection from seizures had shown quite debatable findings. EP2 antagonism using 3-aryl-acrylamide derivatives attenuated SE-induced neuroinflammation and neuronal injury in rodents [55, 89-91]. Conflictingly, few other studies found systemic administration of EP2 agonists to have significant anticonvulsant effect to PTZ- and pilocarpine-induced seizures [92, 93]. This dual effect of EP2 modulation on neuronal activity depends on the latency to seizure onset and thus shows neuroprotection within a tightly regulated therapeutic window $[94,95]$. Such studies question if EP receptors can be considered as potential therapeutic targets in neurological diseases.

Following seizure insults, the developing rat brain showed either no or minor change in COX-2 expression; in contrast, a pronounced increase in COX-2 expression in the adult rat brain was observed $[96,97]$. This suggests that COX-2 induction following seizure is agedependent and the mechanisms regulating its expression and functions are immature in the developing brain [97]. Interestingly, electrically induced SE showed biphasic upregulation of COX-2 in rat hippocampus, an immediate induction at 1 day after SE and induction during spontaneous recurrent seizures (SRS) at the chronic phase, 4-5 months after SE [98]. Moreover, systemic KA administration demonstrated a similar biphasic increase in PG production in the rat hippocampus consisting of an initial burst in the first $30 \mathrm{~min}$ and a sustained late- phase production due to COX-2 induction even with a limited AA supply [24]. This suggests that amidst the acute phase and the chronic phase, some recovery mechanisms are activated, which can prevent the exacerbation of seizure-induced neuronal damage, but failed to prevent epileptogenesis.

In respect of human subjects, so far, only four studies have investigated COX-2 expression profile in the hippocampal tissue from patients with DRTLE [19, 98-100] (Table 1). These studies revealed strong immunohistochemical expression of COX-2 in neurons, astrocytes, and microglial cells of hippocampal sclerotic tissue. While Desjardins et al. suggested the implication of COX-2 induction in the pathogenesis of HS in TLE [101], Weidner et al. found no difference in COX-2 expression between TLE with HS and TLE without HS groups implying COX-2 induction to be independent of presence/absence of HS [100]. More recently, epilepsy researchers began working on the relevance of genetic aspects of COX-2 in people experiencing seizures by investigating associated genetic variants [101].

\section{COX-2-mediated blood-brain barrier disruption}

Regulating the trafficking of circulating molecules between the blood and the brain, there exists a selectively permeable monolayer of brain capillary endothelial cells called BBB. Disruption of this barrier is associated with neurological ailments where it can be a cause or appear as a consequence of the disease [102]. Activation of NMDA receptor by the excitatory neurotransmitter, glutamate, disrupted BBB function and permeability in human brain capillary endothelial cells [103] whereas its inhibition by the antagonist, MK-801, prevented BBB breakdown in isolated rat brain capillary endothelial cells [104], suggesting neuronal over-excitation to cause BBB disruption. Several studies demonstrated BBB disruption to be related to seizure occurrence in humans and rodents [105-109]. It was proposed that the resultant disruption leads to $B B B$ leakage, further causing efflux of administered AEDs [110]. Since the brain as well as brain endothelial cells express several well-characterized $A B C$ efflux transporters such as P-glycoprotein (P-gp), BCRP, MRP1, MRP4, and MRP5 [111], these are often associated with AED resistance attributed to $\mathrm{BBB}$ leakage in epilepsy [7]. Of these transporters, P-gp has been widely studied for causing multidrug resistance in epilepsy due to its upregulation during seizure. Several investigations revealed upregulation of P-gp in the brain and BBB due to seizure activity in rodent models [112-117] as well as in human patients with refractory epilepsy [117-121]. Rats with drugresistant seizures were also shown to exhibit enhanced brain P-gp expression compared to those with drugresponsive seizures [122]. Consequently, the prescribed AEDs gets effluxed out into the circulation by the 
Table 1 Clinical studies reporting COX-2 involvement in epilepsy

\begin{tabular}{|c|c|c|c|c|c|}
\hline Reference & Study type & Tissue & Cells & Study subjects & Reference \\
\hline Desjardins et al. [99] & Expression & Hippocampus & $\begin{array}{l}\text { Astrocytes } \\
\text { and neurons }\end{array}$ & $\begin{array}{l}5 \text { sclerotic and } 2 \\
\text { non-sclerotic DRTLE }\end{array}$ & $\begin{array}{l}\text { Induction of astrocytic COX-2 in } \\
\text { patients with HS suggesting its } \\
\text { implication in the pathogenesis } \\
\text { of HS in epilepsy }\end{array}$ \\
\hline Holtman et al. [98] & Expression & Hippocampus & $\begin{array}{l}\text { Astrocytes } \\
\text { and neurons }\end{array}$ & $\begin{array}{l}6 \text { sclerotic and } 4 \\
\text { non-sclerotic DRTLE } \\
\text { and } 5 \text { controls }\end{array}$ & $\begin{array}{l}\text { Higher astrocytic and neuronal } \\
\text { COX-2 in patients with HS compared } \\
\text { to non-HS and controls }\end{array}$ \\
\hline Das et al. [19] & Expression & Hippocampus & $\begin{array}{l}\text { Astrocytes } \\
\text { and neurons }\end{array}$ & $\begin{array}{l}6 \text { sclerotic DRTLE } \\
\text { and } 3 \text { sudden-death } \\
\text { controls }\end{array}$ & $\begin{array}{l}\text { Increased COX-2 in patients suggesting } \\
\text { its crucial role in TLE pathogenesis }\end{array}$ \\
\hline Hung et al. [101] & Genetic & Whole blood & $\begin{array}{l}\text { White blood } \\
\text { cells }\end{array}$ & $\begin{array}{l}35 \text { children with febrile } \\
\text { seizures and } 31 \text { controls }\end{array}$ & $\begin{array}{l}\text { A single SNP, rs689466, localized at } \\
5^{\prime}-1192 \text { of the PTGS2 gene was } \\
\text { significantly association with } \\
\text { febrile seizures }\end{array}$ \\
\hline Weidner et al. [100] & Expression & Hippocampus & $\begin{array}{l}\text { Microglia, astrocytes } \\
\text { and neurons }\end{array}$ & $\begin{array}{l}16 \text { sclerotic and } 17 \\
\text { non-sclerotic DRTLE }\end{array}$ & $\begin{array}{l}\text { Higher microglial and neuronal } \\
\text { COX-2 expression than astrocytic } \\
\text { COX-2 } \\
\text { No difference in COX-2 levels among } \\
\text { sclerotic and non-sclerotic samples }\end{array}$ \\
\hline
\end{tabular}

upregulated P-gp, even before reaching the drug target, thereby causing pharmacoresistance.

The underlying molecular mechanism behind the regulation of seizure-induced $\mathrm{P}$-gp is currently being investigated in in vivo and in vitro model systems to achieve the goal of decreasing pharmacoresistance and establishing highly efficacious treatment for epilepsy. P-gp had been observed to be upregulated by glutamate-mediated NMDA receptor activation in brain capillary endothelial cells [123-125]. This glutamate-mediated P-gp upregulation was prevented by exposure to selective COX-2 inhibitors such as celecoxib and NS-398 and non-selective inhibitor, indomethacin heptyl ester [124-126], suggesting the involvement of COX-2 in regulating P-gp expression. Brain capillary endothelial cells from pilocarpineinduced SE rat model also showed high P-gp expression and activity which was blocked by treatment with COX-2 inhibitors, indomethacin and celecoxib [124, 126], revealing the role of COX-2 in seizure-induced P-gp upregulation. Similarly, administration of COX-2 inhibitors, SC-58236 and NS-398, both counteracted the SE-associated increase in P-gp expression in the parahippocampal cortex and the ventral hippocampus in rats [127]. Besides, blocking the EP1 receptor by the antagonist, SC-51089, in pilocarpine-induced SE rat model prevented seizure-induced P-gp upregulation [128]. These investigations indicated that activation of COX-2/EP receptor signaling during seizure is somehow causing upregulation of $\mathrm{P}$-gp, thereby leading to decreased drug delivery to the brain and enhanced resistance to drugs. Direct inhibition of P-gp may improve seizure control; however, its pan inhibition may lead to deleterious effects [129]. Moreover, when a known P-gp inhibitor, verapamil, was administered to pediatric patients, children with drug-resistant epilepsy receiving AED polytherapy showed no significant difference in seizure control compared to those receiving placebo along with AED polytherapy [130]. Likewise, inhibition of multiple EP receptors simultaneously may produce adverse effects. This signifies the importance of targeting the upstream regulatory molecule, COX-2, for a potential future strategy for epilepsy treatment.

\section{COX-2 inhibitors: therapeutic strategies}

Non-steroidal anti-inflammatory drugs (NSAIDs), the currently available COX inhibitory drugs, prevent the formation of PGs by competitively inhibiting the activity of COX enzymes. NSAIDs are of two types: selective, which inhibit only COX-2 (e.g., celecoxib and rofecoxib), and nonselective, which inhibit both COX-1 and COX-2 (e.g., aspirin, ibuprofen, and indomethacin). These inhibitors work by varying degrees of reversible (example, ibuprofen and indomethacin) or irreversible (example, celecoxib, rofecoxib, and aspirin) competitive inhibition. NSAIDs help in mitigating different manifestations of allergic reactions and provide antipyretic, analgesic, and anti-platelet effects in acute and chronic conditions; however, they also have several undesirable effects. Due to the protective role of COX1 in the maintenance of the stomach lining by preventing it from stomach acid, its inhibition sometimes causes gastric problems. In response to this challenge, new generational NSAIDs, specific to COX-2, were developed. However, the selective COX-2 inhibitors, coxibs, can increase the risk of adverse renal and cardiovascular events and thus require improvisation for better efficacy without any complications. 


\section{COX-2 inhibitors as anticonvulsants}

To ascertain the anticonvulsive therapeutic potential of COX-2 inhibition, several studies investigated the effect of COX-2 inhibitors on seizure activity and development in animal models of epilepsy (Table 2). The findings differ with different seizure and treatment conditions. Dhir et al. 2006a examined the effect of selective COX-2 inhibitors, nimesulide and rofecoxib, administered $45 \mathrm{~min}$ prior to an epileptic challenge in different mice models [138]. They found that the inhibitors prolonged the mean onset time of convulsions and decreased the seizure duration and the percentage mortality rate against bicuculline- and picrotoxin-induced seizures; however, they did not affect maximal electroshock-induced seizures, suggesting varied efficacy of COX-2 inhibitors in different types of convulsive challenge. Another study by the same group revealed the two selective COX-2 inhibitors to be more efficacious than non-selective COX-2 inhibitors, aspirin and naproxen [140], in antagonizing the effect of PTZ-induced seizures. The authors also found that nimesulide provides a neuroprotective effect by controlling the biochemical alterations caused by PTZ-induced chemical kindling in mice [141]. Administration of $2 \mathrm{mg} / \mathrm{kg}$ and $4 \mathrm{mg} / \mathrm{kg}$ of rofecoxib increased the seizure threshold; however, a lower dose of $1 \mathrm{mg} / \mathrm{kg}$ of rofecoxib failed to do the same, indicating a dosedependent effect [145]. Pretreatment of selective COX-2 inhibitor, celecoxib, $60 \mathrm{~min}$ prior to seizure induction also demonstrated anticonvulsant effects in the PTZinduced rat model [84]. Conversely, several studies suggest that pretreatment of selective or non-selective COX-2 inhibitors may have an inverse effect by acting as proconvulsants $[132-134,139,151]$, and a postictal COX-2 inhibition would rather have a neuroprotective effect $[132,142,144,149,150]$. After PTZ challenge to male Wistar rats, the selective COX-2 inhibitor,

Table 2 Preclinical evidences supporting or opposing clinical application of COX-2 inhibitors for epilepsy treatment

\begin{tabular}{|c|c|c|c|c|}
\hline Selectivity & Drug & Type of convulsive challenge & Supporting evidences & Opposing evidences \\
\hline \multirow[t]{20}{*}{ Selective } & \multirow[t]{5}{*}{ Celecoxib } & Electrical stimulation & {$[131]$} & [87] \\
\hline & & Flurothyl & {$[96]$} & - \\
\hline & & Kainic acid & [132] & {$[133,134]$} \\
\hline & & Pentylenetetrazol & {$[84]$} & - \\
\hline & & Pilocarpine & {$[126,135]$} & - \\
\hline & \multirow[t]{2}{*}{ Etoricoxib } & Genetic model & [136] & - \\
\hline & & Pentylenetetrazol & [137] & - \\
\hline & \multirow[t]{5}{*}{ Nimesulide } & Bicuculline & [138] & - \\
\hline & & Electrical stimulation & {$[6,23]$} & - \\
\hline & & Kainic acid & - & {$[134,139]$} \\
\hline & & Pentylenetetrazol & {$[140,141]$} & - \\
\hline & & Picrotoxin & [138] & - \\
\hline & \multirow[t]{2}{*}{ NS-398 } & Kainic acid & {$[83]$} & [133] \\
\hline & & Pilocarpine & {$[127,142]$} & - \\
\hline & Parecoxib & Pilocarpine & {$[143]$} & - \\
\hline & \multirow[t]{2}{*}{ Rofecoxib } & Kainic acid & {$[144]$} & - \\
\hline & & Pentylenetetrazol & {$[56,140,145]$} & {$[146]$} \\
\hline & SC-58125 & Kainic acid & {$[82]$} & - \\
\hline & \multirow[t]{2}{*}{ SC-58236 } & Electrical stimulation & - & {$[98,147]$} \\
\hline & & Pilocarpine & [127] & - \\
\hline \multirow[t]{8}{*}{ Non-selective } & \multirow[t]{3}{*}{ Aspirin } & Electrical stimulation & [148] & - \\
\hline & & Kainic acid & - & [133] \\
\hline & & Pilocarpine & {$[149,150]$} & [151] \\
\hline & Ibuprofen & Electrical stimulation & {$[148]$} & - \\
\hline & \multirow[t]{2}{*}{ Indomethacin } & Electrical stimulation & [148] & - \\
\hline & & Kainic acid & - & {$[133,151]$} \\
\hline & \multirow{2}{*}{$\begin{array}{l}\text { Others (metamizole, paracetamol, } \\
\text { piroxicam, ketoprofen) }\end{array}$} & Electrical stimulation & [148] & - \\
\hline & & Kainic acid & - & [134] \\
\hline
\end{tabular}


etoricoxib, showed an anticonvulsant effect at a dose of $1 \mathrm{mg} / \mathrm{kg}$ which got reduced or reversed at $10 \mathrm{mg} / \mathrm{kg}$ of dose displaying the neuroprotective effect within a narrow therapeutic dose window [137].

Celecoxib administration 1 day after pilocarpine-induced SE reduced the likelihood of developing SRS and prevented hippocampal neuronal damage in rats [135]. Early longterm treatment of another coxib drug, etoricoxib, also displayed antiepileptogenic effect by reducing the development of absence seizures in the genetic WAG/Rij rat model of absence epilepsy [136]. However, several reports contradict these findings. Administration of rofecoxib 5 days prior to epileptic challenge showed no effect on PTZ-kindling development [146]. A 3-day treatment with the selective COX-2 inhibitor, SC-58326, starting 1 day before electrically induced SE increased rat mortality in models of TLE [147] while a 7-day treatment starting $4 \mathrm{~h}$ after SE induction effectively reduced $\mathrm{PGE}_{2}$ production but did not prevent seizure development or neuronal damage [98]. Similarly, an 18-day administration of the selective COX-2 inhibitor, parecoxib, following pilocarpine-induced SE prevented the subsequent increase in $\mathrm{PGE}_{2}$ and reduced seizure severity in the rat hippocampus and piriform cortex; however, it could not prevent the development, frequency, and duration of seizures [143]. These studies demonstrate an anticonvulsive but not antiepileptogenic effect of COX-2 inhibitors. It is proposed that COX-2 inhibitors display this anticonvulsive activity by reducing the production of $\mathrm{PGE}_{2}$ causing decreased activation of EP receptors which, in turn, lowers calcium ion influx and release of the excitatory neurotransmitter, glutamate, thus blocking the seizures [152] (Fig. 2a). Simultaneously, COX-2 inhibitors suppress the production of pro-inflammatory cytokines reducing inflammation [72-74].

In vivo studies reporting the effect of COX-2 inhibitors on seizure activity revealed that various factors determine the anticonvulsant action of these drugs viz., dosage, time of administration, treatment duration, type of convulsive challenge, and selectivity of COX-2 inhibitors. Based on these factors, COX-2 inhibitors, alike EP receptors, can produce dichotomous effects, neuroprotective or neurotoxic [153], suggesting the need to optimize their therapeutic dose, time, treatment duration, and other pharmacokinetic and pharmacodynamic properties. However, instead of targeting multiple EP receptors, targeting the upstream COX-2 enzyme would produce a broad-spectrum effect and therefore remains the key therapeutic target for epilepsy treatment.

\section{COX-2 inhibitors as adjunctive to AED therapy}

As discussed earlier, COX-2 may regulate the expression of the multidrug transporter, $\mathrm{P}$-gp, which is found to be overexpressed in drug-resistant epilepsy. COX-2 upregulation following seizure produces higher levels of $\mathrm{PGE}_{2}$, which when bound to the EP1 receptor, activates a signaling cascade involving the transcription factor, NF- $\mathrm{kB}$,

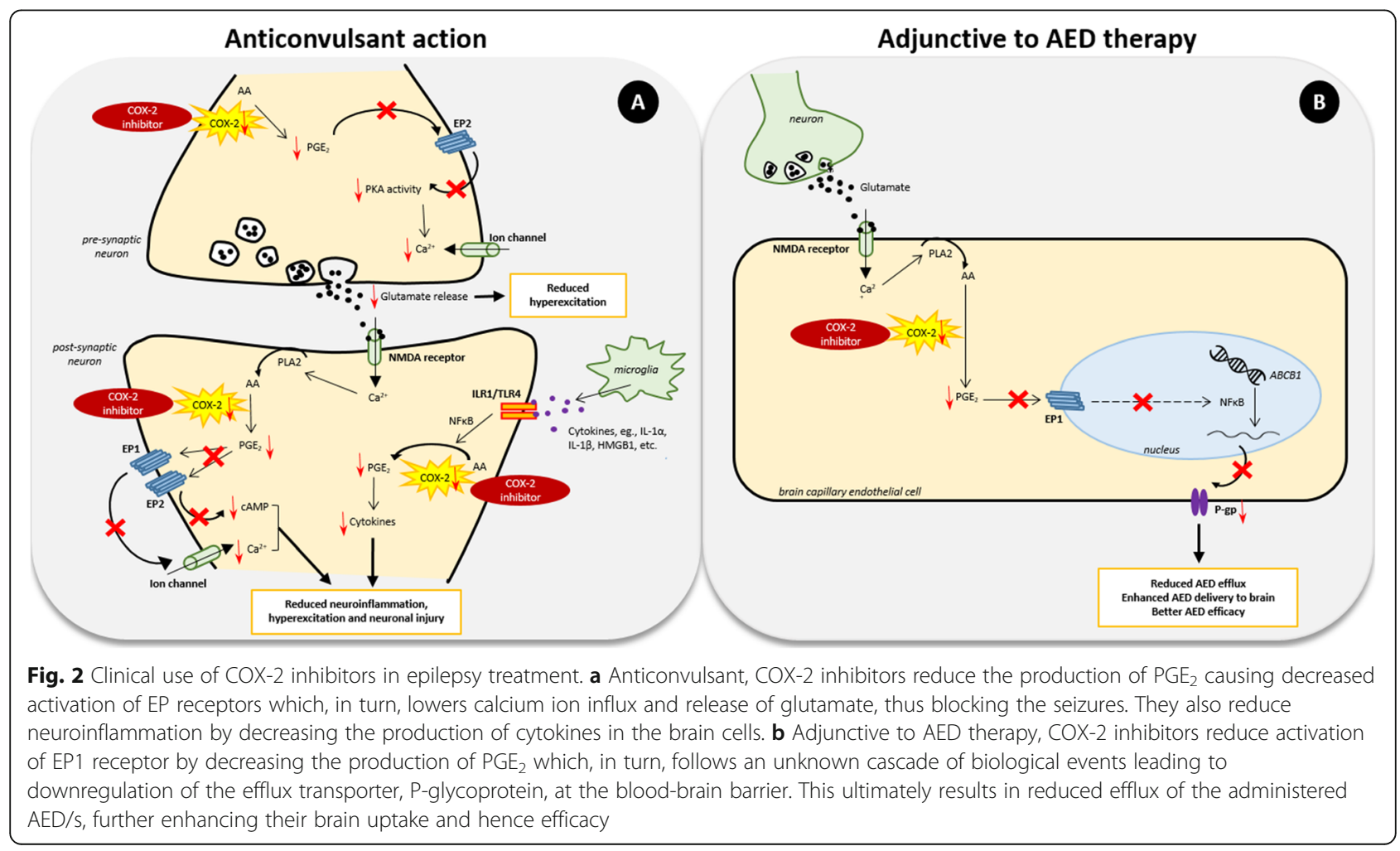


leading to increased expression of P-gp [7]. Overexpression of P-gp at the BBB may result in enhanced the efflux of the prescribed $\mathrm{AED} / \mathrm{s}$ even before reaching the target site in the brain, causing pharmacoresistance. Blocking seizure-mediated P-gp overexpression in the brain capillary endothelial cells, therefore, may facilitate better drug delivery to the brain and improve drug efficacy provided the prescribed AED is a substrate of P-gp. Several studies have investigated different AEDs as potential substrates of P-gp. Phenytoin, phenobarbital, lamotrigine, and levetiracetam have widely been observed to be weak but potential substrates of P-gp while carbamazepine, felbamate, and ethosuximide had no substrate interaction with the transporter [154]. Other drugs have shown either contradictory findings or remain insufficiently investigated in this regard.

Overexpression of P-gp at the BBB decreased brain uptake of phenytoin at specific limbic brain regions of chronic epileptic rats [155]. Its direct inhibition using three different P-gp inhibitors resulted in increased phenytoin concentration in brain extracellular fluid (ECF) in rats [156]. Treatment with selective P-gp inhibitor, tariquidar, improved seizure control in chronic epileptic rats due to increased phenytoin delivery to the brain $[155,157]$. Despite these beneficial findings of direct P-gp inhibition, its pan inhibition may lead to deleterious effect [129], thus an alternative indirect approach is required for its suppression. Since COX-2 serves as a transcriptional regulator of $\mathrm{P}$-gp, inhibiting COX-2 may assist in achieving enhanced efficacy of prescribed AEDs (Fig. 2b). In vitro data revealed prevention of glutamateinduced P-gp upregulation by selective and non-selective COX-2 inhibitors in rodent and human brain capillary endothelial cells [124-126]. COX-2 inhibitors also blocked SE-induced P-gp upregulation in the brain capillaries of epileptic rats, revealing the role of COX-2 inhibitors in preventing seizure-induced P-gp upregulation $[124,126]$. Furthermore, brain uptake of phenytoin was significantly enhanced by sub-chronic COX-2 inhibition via suppressing P-gp expression in chronic epileptic rats, suggesting that COX-2 inhibitors may help in increasing drug delivery to the target sites in the brain [127]. To relate this effect of COX-2 inhibitors with the drug efficacy, Schlichtiger et al. investigated the outcome of celecoxib treatment in phenobarbital-treated responder and non-responder epileptic rats [131]. A 6-day treatment with celecoxib significantly reduced P-gp expression as well as frequency of SRS in both the responders and non-responders suggesting the potential role of COX-2 inhibition in increasing AED efficacy via downregulating P-gp. Rofecoxib also potentiated the anticonvulsant activity of the AED, tiagabine, against PTZinduced seizures in mice [56]. Non-selective NSAIDs such aspirin, ibuprofen, indomethacin, metamizole, paracetamol, and piroxicam also enhanced the anticonvulsive activity of valproate while the anticonvulsive activity of phenytoin was increased only by ibuprofen and piroxicam against maximal electroshock-induced seizures in mice [148]. Therefore, besides their anticonvulsive effect, COX-2 inhibitors also show a great promise towards being an adjunctive therapy for improving the efficacy of administered AEDs.

\section{Human clinical studies}

Despite decades of extensive research on the beneficial role of COX-2 inhibition in controlling seizure and drug-resistance in epilepsy, the selective COX-2 inhibitors have, so far, not been clinically tested in patients with epilepsy due to their severe adverse effects. However, a recent report by Lim et al. [158] investigated the effect of celecoxib on the neuronal excitability and electrophysiological properties of the brain of healthy volunteers. Though the authors found no effect of celecoxib on the neuronal excitability of the healthy volunteers, the study is limited due to the absence of inflammation in the healthy subjects to observe the effect of the anti-inflammatory drug, celecoxib. In regard to the non-selective COX-2 inhibitors, aspirin, having relatively fewer side effects, has been investigated independently or in adjunction to AED therapy for controlling seizures in epilepsy and related syndromes (Table 3) to substantiate the findings of preclinical studies reporting efficient seizure reduction upon administration of $\mathrm{COX}-2$ inhibitors (Table 2). Most of these studies were performed on patients with the rare neurological disorder, Sturge-Weber syndrome, limiting the current knowledge on the applicability of these drugs for other seizure disorders or epilepsy. Long-term continuous use of aspirin in patients with Sturge-Weber syndrome resulted in seizure freedom for at least 1 year in five of six patients [160]. An internet-based survey involving patients with Sturge-Weber syndrome receiving aspirin reported seizure reduction in 21 of 34 patients [161], suggesting the use of low-dose aspirin to be safe and beneficial. The findings were further validated by Lance et al. who observed seizure control in $91 \%$ of the patients with the syndrome receiving low-dose aspirin with minimal side effects [162]. Patients with focal epilepsy receiving aspirin also showed significantly fewer seizures compared to age-, sex- and disease-matched controls not receiving aspirin [163]. They found an inverse correlation between aspirin doses and seizure frequency. However, a randomized, double-blind, placebo-controlled trial failed to demonstrate a preventive effect of another non-selective NSAID, ibuprofen, on the number of febrile seizure recurrences in 230 children at increased 
Table 3 Clinical evidences using non-selective NSAIDs in patients experiencing seizures

\begin{tabular}{|c|c|c|c|c|}
\hline Reference & NSAID & Use & Study subjects & Effects \\
\hline van Stuijvenberg et al. [159] & Ibuprofen & Independent & $\begin{array}{l}\text { Randomized, double-blind, placebo- } \\
\text { controlled study in } 230 \text { children with } \\
\text { febrile seizures (111 on ibuprofen } \\
\text { and } 119 \text { on placebo) }\end{array}$ & $\begin{array}{l}\text { Failed to reduce number } \\
\text { of seizure recurrences in } \\
\text { children at increased risk }\end{array}$ \\
\hline Udani et al. [160] & Aspirin & Not reported & $\begin{array}{l}9 \text { children with Sturge-Weber syndrome } \\
\text { ( } 6 \text { with long-term continuous aspirin therapy } \\
\text { and } 3 \text { with intermittent use of aspirin) }\end{array}$ & $\begin{array}{l}\text { Seizure freedom for at least } \\
\text { one year in } 8 \text { of } 9 \text { children }\end{array}$ \\
\hline Bay et al. [161] & Aspirin & $\begin{array}{l}\text { In adjunction to } \\
\text { AED therapy }\end{array}$ & $\begin{array}{l}\text { Internet-based survey in } 34 \text { subjects } \\
\text { with Sturge-Weber syndrome receiving } \\
\text { aspirin }\end{array}$ & $\begin{array}{l}\text { Seizure reduction in } 21 \text { of } \\
34 \text { patients }\end{array}$ \\
\hline Lance et al. [162] & Aspirin & $\begin{array}{l}\text { In adjunction to } \\
\text { AED therapy }\end{array}$ & $\begin{array}{l}58 \text { subjects with Sturge-Weber syndrome } \\
\text { receiving aspirin }\end{array}$ & $\begin{array}{l}\text { Seizure control in } 91 \% \text { of the } \\
\text { patients }\end{array}$ \\
\hline Godfred et al. [163] & Aspirin & Independent & $\begin{array}{l}46 \text { subjects with focal epilepsy ( } 23 \text { receiving } \\
\text { aspirin and } 23 \text { not receiving aspirin) }\end{array}$ & $\begin{array}{l}\text { Fewer seizures in patients on } \\
\text { aspirin therapy than patients } \\
\text { not receiving it }\end{array}$ \\
\hline
\end{tabular}

risk [159] (Table 3). Therefore, studies revealing the anticonvulsive effect of aspirin require replication in a large-sample, randomized, controlled trial to substantiate the effect and applicability of COX-2 inhibitors as a therapeutic approach in epilepsy management.

\section{Conclusion}

Increasing evidences on the role of inflammation in epilepsy pathogenesis are encouraging researchers to gather information on the clinical use of neuroinflammation-targeted therapeutics and to develop their better, improved, efficacious analogues. COX-2, a proinflammatory enzyme interconnecting various inflammatory processes, is widely being investigated as a therapeutic target in epilepsy. Several preclinical and clinical studies demonstrated COX-2 induction during a seizure event and in epilepsy. Pharmacological inhibition of COX-2 enzyme using selective and non-selective COX-2 inhibitors not only resulted in reduced seizure recurrence and disease severity but also increased the efficacy of administered AEDs, suggesting their two probable modes of action, (1) anticonvulsive and (2) adjunctive to AED therapy. However, the efficacy of COX-2 inhibitors depends on various factors such as viz., therapeutic dose, time of administration, treatment duration, and their selectivity and is often accompanied by mild or severe adverse effects, thus prompting further investigations on improvising the efficacy and optimizing their use without any complications. In addition, future studies should also focus on investigating the anticonvulsive effect of COX-2 inhibitors in large-sample, randomized, controlled trials to substantiate the clinical application of COX-2 inhibitors as a future therapeutic strategy for epilepsy management.

\section{Abbreviations}

AA: Arachidonic acid; ABC: ATP-binding cassette; AED: Antiepileptic drug; BBB: Blood-brain barrier; CNS: Central nervous system; COX: Cyclooxygenase; CSF: Cerebrospinal fluid; DRTLE: Drug-resistant temporal lobe epilepsy; ECF: Extracellular fluid; GABA: $\gamma$-Aminobutyric acid; GPCR: G protein-coupled receptor; HS: Hippocampal sclerosis; KA: Kainic acid; LPS: Lipopolysaccharide; NMDA: N-Methyl-D-aspartate; NO: Nitric oxide; NSAID: Non-steroidal antiinflammatory drug; PG: Prostaglandin; P-gp: P-glycoprotein;

PTZ: Pentylenetetrazol; SE: Status epilepticus; TLE: Temporal lobe epilepsy

\section{Acknowledgements}

We thank Dr. Anurag Agrawal, Director, Institute of Genomics and Integrative Biology (IGIB), for his motivation and unconditional support. CR and URD acknowledge University Grants Commission (UGC), and SK acknowledges Department of Biotechnology (DBT) for providing fellowships.

\section{Authors' contributions}

CR and RK conceived the idea. CR, SK, URD, and RK wrote and reviewed the article. The entire article was written under the supervision of RK. All the authors read and approved the final manuscript.

\section{Funding}

This work was funded by Council of Scientific and Industrial Research (CSIR), MLP1804.

Availability of data and materials Not applicable.

Ethics approval and consent to participate Not applicable.

\section{Consent for publication}

Not applicable.

\section{Competing interests}

The authors declare that they have no competing interests.

Received: 29 November 2018 Accepted: 23 September 2019

Published online: 30 October 2019

\section{References}

1. Fisher RS, Acevedo C, Arzimanoglou A, Bogacz A, Cross JH, Elger CE, et al. ILAE official report: a practical clinical definition of epilepsy. Epilepsia. 2014; 55:475-82.

2. Laxer KD, Trinka E, Hirsch LJ, Cendes F, Langfitt J, Delanty N, et al. The consequences of refractory epilepsy and its treatment. Epilepsy Behav. 2014; 37:59-70.

3. Vezzani A, French J, Bartfai T, Baram TZ. The role of inflammation in epilepsy. Nat Rev Neurol. 2011;7:31-40.

4. Vezzani A, Viviani B. Neuromodulatory properties of inflammatory cytokines and their impact on neuronal excitability. Neuropharmacology. 2015;96:70-82. 
5. Dey A, Kang X, Qiu J, Du Y, Jiang J. Anti-inflammatory small molecules to treat seizures and epilepsy: from bench to bedside. Trends Pharmacol Sci. 2016;37:463-84.

6. Takemiya T, Suzuki K, Sugiura H, Yasuda S, Yamagata K, Kawakami Y, et al. Inducible brain COX-2 facilitates the recurrence of hippocampal seizures in mouse rapid kindling. Prostaglandins Other Lipid Mediat. 2003;71:205-16.

7. Potschka H. Modulating P-glycoprotein regulation: future perspectives for pharmacoresistant epilepsies? Epilepsia. 2010;51:1333-47.

8. Sheng JG, Boop FA, Mrak RE, Griffin WS. Increased neuronal $\beta$-amyloid precursor protein expression in human temporal lobe epilepsy: association with interleukin-1a immunoreactivity. J Neurochem. 1994;63:1872-9.

9. Kanemoto K, Kawasaki J, Miyamoto T, Obayashi H, Nishimura M. Interleukin (IL)1 beta, IL-1alpha, and IL-1 receptor antagonist gene polymorphisms in patients with temporal lobe epilepsy. Ann Neurol. 2000;47:571-4.

10. Ichiyama T, Nishikawa M, Yoshitomi T, Hayashi T, Furukawa S. Tumor necrosis factor-alpha, interleukin-1 beta, and interleukin-6 in cerebrospinal fluid from children with prolonged febrile seizures. Comparison with acute encephalitis/encephalopathy. Neurology. 1998;50:407-11.

11. Shi LM, Chen RJ, Zhang H, Jiang CM, Gong J. Cerebrospinal fluid neuron specific enolase, interleukin-1 $\beta$ and erythropoietin concentrations in children after seizures. Childs Nerv Syst. 2017;33:805-11.

12. Uludag IF, Duksal T, Tiftikcioglu BI, Zorlu Y, Ozkaya F, Kirkali G. IL-1ß, IL-6 and IL1Ra levels in temporal lobe epilepsy. Seizure. 2015;26:22-5.

13. Wang Y, Wang D, Guo D. Interictal cytokine levels were correlated to seizure severity of epileptic patients: a retrospective study on 1218 epileptic patients. J Transl Med. 2015;13:378.

14. Lorigados Pedre L, Morales Chacón LM, Pavón Fuentes N, Robinson Agramonte MLA, Serrano Sánchez T, Cruz-Xenes RM, et al. Follow-up of peripheral IL-1 $\beta$ and IL-6 and relation with apoptotic death in drug-resistant temporal lobe epilepsy patients submitted to surgery. Behav Sci. 2018;8:21.

15. Lee TS, Mane S, Eid T, Zhao H, Lin A, Guan Z, et al. Gene expression in temporal lobe epilepsy is consistent with increased release of glutamate by astrocytes. Mol Med. 2007;13:1-13.

16. Xu Y, Zeng K, Han Y, Wang L, Chen D, Xi Z, et al. Altered expression of CX3CL1 in patients with epilepsy and in a rat model. Am J Pathol. 2012;180:1950-62.

17. Li R, Ma L, Huang H, Ou S, Yuan J, Xu T, et al. Altered expression of CXCL13 and CXCR5 in intractable temporal lobe epilepsy patients and pilocarpineinduced epileptic rats. Neurochem Res. 2017;42:526-40.

18. Crespel A, Coubes P, Rousset MC, Brana C, Rougier A, Rondouin G, et al. Inflammatory reactions in human medial temporal lobe epilepsy with hippocampal sclerosis. Brain Res. 2002;952:159-69.

19. Das A, Wallace GC 4th, Holmes C, McDowell ML, Smith JA, Marshall JD, et al. Hippocampal tissue of patients with refractory temporal lobe epilepsy is associated with astrocyte activation, inflammation, and altered expression of channels and receptors. Neuroscience. 2012;220:237-46.

20. De Simoni MG, Perego C, Ravizza T, Moneta D, Conti M, Marchesi F, et al. Inflammatory cytokines and related genes are induced in the rat hippocampus by limbic status epilepticus. Eur J Neurosci. 2000;12:2623-33.

21. Xu JH, Long L, Tang YC, Zhang JT, Hut HT, Tang FR. CCR3, CCR2A and macrophage inflammatory protein (MIP)-1a, monocyte chemotactic protein1 (MCP-1) in the mouse hippocampus during and after pilocarpine-induced status epilepticus (PISE). Neuropathol Appl Neurobiol. 2009;35:496-514.

22. Gorter JA, van Vliet EA, Aronica E, Breit T, Rauwerda H, Lopes da Silva FH, et al. Potential new antiepileptogenic targets indicated by microarray analysis in a rat model for temporal lobe epilepsy. J Neurosci 2006;26(43): 11083-11110.

23. Tu B, Bazan NG. Hippocampal kindling epileptogenesis upregulates neuronal cyclooxygenase-2 expression in neocortex. Exp Neurol. 2003;179:167-75.

24. Yoshikawa K, Kita Y, Kishimoto K, Shimizu T. Profiling of eicosanoid production in the rat hippocampus during kainic acid-induced seizure: dual phase regulation and differential involvement of COX-1 and COX-2. J Biol Chem. 2006;281:14663-9.

25. Auvin S, Shin D, Mazarati A, Nakagawa J, Miyamoto J, Sankar R. Inflammation exacerbates seizure-induced injury in the immature brain. Epilepsia. 2007;48(Suppl 5):27-34.

26. Auvin S, Shin D, Mazarati A, Sankar R. Inflammation induced by LPS enhances epileptogenesis in immature rat and may be partially reversed by IL1RA. Epilepsia. 2010;51(Suppl 3):34-8.

27. Dube C, Vezzani A, Behrens M, Bartfai T, Baram TZ. Interleukin-1 beta contributes to the generation of experimental febrile seizures. Ann Neurol. 2005;57:152-5.
28. Cacheaux LP, Ivens S, David Y, Lakhter AJ, Bar-Klein G, Shapira M, et al. Transcriptome profiling reveals TGF-beta signaling involvement in epileptogenesis. J Neurosci. 2009;29:8927-35.

29. Kovacs R, Rabanus A, Otahal J, Patzak A, Kardos J, Albus K, et al. Endogenous nitric oxide is a key promoting factor for initiation of seizure-like events in hippocampal and entorhinal cortex slices. J Neurosci. 2009;29:8565-77.

30. Maroso M, Balosso S, Ravizza T, Liu J, Aronica E, lyer AM, et al. Toll-like receptor 4 and high-mobility group box-1 are involved in ictogenesis and can be targeted to reduce seizures. Nat Med. 2010;16:413-9.

31. Pernhorst K, Herms S, Hoffmann P, Cichon S, Schulz H, Sander T, et al. TLR4, ATF-3 and IL8 inflammation mediator expression correlates with seizure frequency in human epileptic brain tissue. Seizure. 2013;22:675-8.

32. Brodie MJ, Sills GJ. Combining antiepileptic drugs--rational polytherapy? Seizure. 2011;20:369-75.

33. Sirven Jl, Noe K, Hoerth M, Drazkowski J. Antiepileptic drugs 2012: recent advances and trends. Mayo Clin Proc. 2012;87:879-89.

34. Lynch BA, Lambeng N, Nocka K, Kensel-Hammes P, Bajjalieh SM, Matagne A, et al. The synaptic vesicle protein SV2A is the binding site for the antiepileptic drug levetiracetam. Proc Natl Acad Sci U S A. 2004;101:9861-6.

35. Loscher W, Klitgaard H, Twyman RE, Schmidt D. New avenues for anti-epileptic drug discovery and development. Nat Rev Drug Discov. 2013;12:757-76.

36. Schmidt D, Loscher W. New developments in antiepileptic drug resistance: an integrative view. Epilepsy Curr. 2009;9:47-52.

37. Tate SK, Depondt C, Sisodiya SM, Cavalleri GL, Schorge S, Soranzo N, et al. Genetic predictors of the maximum doses patients receive during clinical use of the anti-epileptic drugs carbamazepine and phenytoin. Proc Natl Acad Sci U S A. 2005;102:5507-12.

38. Abe T, Seo T, Ishitsu T, Nakagawa T, Hori M, Nakagawa K. Association between SCN1A polymorphism and carbamazepine-resistant epilepsy. Br J Clin Pharmacol. 2008;66:304-7.

39. Kumari R, Lakhan R, Kalita J, Misra UK, Mittal B. Association of alpha subunit of GABAA receptor subtype gene polymorphisms with epilepsy susceptibility and drug resistance in north Indian population. Seizure. 2010;19:237-41.

40. Kwan P, Poon WS, Ng HK, Kang DE, Wong V, Ng PW, et al. Multidrug resistance in epilepsy and polymorphisms in the voltage-gated sodium channel genes SCN1A, SCN2A, and SCN3A: correlation among phenotype, genotype, and mRNA expression. Pharmacogenet Genomics. 2008;18:989-98.

41. Kwan $P$, Brodie MJ. Potential role of drug transporters in the pathogenesis of medically intractable epilepsy. Epilepsia. 2005;46:224-35.

42. Dombrowski SM, Desai SY, Marroni M, Cucullo L, Goodrich K, Bingaman W, et al. Overexpression of multiple drug resistance genes in endothelial cells from patients with refractory epilepsy. Epilepsia. 2001;42:1501-6.

43. Banerjee Dixit A, Sharma D, Srivastava A, Banerjee J, Tripathi M, Prakash D, et al. Upregulation of breast cancer resistance protein and major vault protein in drug resistant epilepsy. Seizure. 2017;47:9-12.

44. Kubota $H$, Ishihara $H$, Langmann $T$, Schmitz $G$, Stieger B, Wieser HG, et al. Distribution and functional activity of P-glycoprotein and multidrug resistance-associated proteins in human brain microvascular endothelial cells in hippocampal sclerosis. Epilepsy Res. 2006;68:213-28.

45. Rogawski MA. The intrinsic severity hypothesis of pharmacoresistance to antiepileptic drugs. Epilepsia. 2013;54(Suppl 2):33-40.

46. Kwan P, Brodie MJ. Early identification of refractory epilepsy. N Engl J Med. 2000;342:314-9.

47. Rawat C, Guin D, Talwar P, Grover S, Baghel R, Kushwaha S, et al. Clinical predictors of treatment outcome in North Indian patients on antiepileptic drug therapy: a prospective observational study. Neurol India. 2018;66:1052-9.

48. Kobow K, El-Osta A, Blumcke I. The methylation hypothesis of pharmacoresistance in epilepsy. Epilepsia. 2013;54(Suppl 2):41-7.

49. Kim JE, Choi HC, Song HK, Jo SM, Kim DS, Choi SY, et al. Levetiracetam inhibits interleukin-1 beta inflammatory responses in the hippocampus and piriform cortex of epileptic rats. Neurosci Lett. 2010;471:94-9.

50. Gomez CD, Buijs RM, Sitges M. The anti-seizure drugs vinpocetine and carbamazepine, but not valproic acid, reduce inflammatory IL-1 $\beta$ and TNF- $a$ expression in rat hippocampus. J Neurochem. 2014;130:770-9.

51. Verrotti A, Basciani F, Trotta D, Greco R, Morgese G, Chiarelli F. Effect of anticonvulsant drugs on interleukins-1, -2 and -6 and monocyte chemoattractant protein-1. Clin Exp Med. 2001;1:133-6.

52. Vezzani A, Moneta D, Conti M, Richichi C, Ravizza T, De Luigi A, et al. Powerful anticonvulsant action of $\mathrm{IL}-1$ receptor antagonist on intracerebral injection and astrocytic overexpression in mice. Proc Natl Acad Sci U S A. 2000;97:11534-9. 
53. Ravizza T, Lucas SM, Balosso S, Bernardino L, Ku G, Noé F, et al. Inactivation of caspase-1 in rodent brain: a novel anticonvulsive strategy. Epilepsia. 2006; 47:1160-8.

54. Iori V, Iyer AM, Ravizza T, Beltrame L, Paracchini L, Marchini S, et al. Blockade of the IL-1R1/TLR4 pathway mediates disease-modification therapeutic effects in a model of acquired epilepsy. Neurobiol Dis. 2017;99:12-23.

55. Jiang J, Ganesh T, Du Y, Quan Y, Serrano G, Qui M, et al. Small molecule antagonist reveals seizure-induced mediation of neuronal injury by prostaglandin E2 receptor subtype EP2. Proc Natl Acad Sci U S A. 2012;109:3149-54.

56. Dhir A, Kulkarni SK. Rofecoxib, a selective cyclooxygenase-2 (COX-2) inhibitor potentiates the anticonvulsant activity of tiagabine against pentylenetetrazol-induced convulsions in mice. Inflammopharmacology. 2006;14:222-5

57. Maher RL, Hanlon J, Hajjar ER. Clinical consequences of polypharmacy in elderly. Expert Opin Drug Saf. 2014;13(1):57-65.

58. Molina-Holgado E, Ortiz S, Molina-Holgado F, Guaza C. Induction of COX-2 and PGE(2) biosynthesis by IL-1 beta is mediated by PKC and mitogen-activated protein kinases in murine astrocytes. $\mathrm{Br} J$ Pharmacol. 2000;131:152-9.

59. Hoozemans JJ, Veerhuis R, Janssen I, Rozemuller AJ, Eikelenboom P. Interleukin-1 beta induced cyclooxygenase 2 expression and prostaglandin E2 secretion by human neuroblastoma cells: implications for Alzheimer's disease. Exp Gerontol. 2001;36:559-70.

60. Leclerc P, Wahamaa H, Idborg H, Jakobsson PJ, Harris HE, Korotkova M. IL$1 \beta / H M G B 1$ complexes promote the PGE2 biosynthesis pathway in synovial fibroblasts. Exp Gerontol Scand J Immunol. 2013;77:350-60.

61. Mark KS, Trickler WJ, Miller DW. Tumor necrosis factor-alpha induces cyclooxygenase-2 expression and prostaglandin release in brain microvessel endothelial cells. J Pharmacol Exp Ther. 2001;297:1051-8.

62. Pettus BJ, Bielawski J, Porcelli AM, Reames DL, Johnson KR, Morrow J, et al. The sphingosine kinase 1/sphingosine-1-phosphate pathway mediates COX-2 induction and PGE2 production in response to TNFalpha. FASEB J. 2003;17:1411-21.

63. Lin CC, Hsiao LD, Chien CS, Lee CW, Hsieh JT, Yang CM. Tumor necrosis factor-alpha-induced cyclooxygenase-2 expression in human tracheal smooth muscle cells: involvement of p42/p44 and p38 mitogen-activated protein kinases and nuclear factor-kappaB. Cell Signal. 2004;16:597-607.

64. Ogata S, Kubota Y, Yamashiro T, Takeuchi H, Ninomiya T, Suyama Y, et al. Signaling pathways regulating IL-1alpha-induced COX-2 expression. J Dent Res. 2007:86:186-91.

65. Cao DL, Zhang ZJ, Xie RG, Jiang BC, Ji RR, Gao YJ. Chemokine CXCL1 enhances inflammatory pain and increases NMDA receptor activity and COX-2 expression in spinal cord neurons via activation of CXCR2. Exp Neurol. 2014;261:328-36.

66. Lin PS, Cheng RH, Chang MC, Lee JJ, Chang HH, Huang WL, et al. TGF- $\beta 1$ stimulates cyclooxygenase-2 expression and PGE2 production of human dental pulp cells: role of ALK5/Smad2 and MEK/ERK signal transduction pathways. J Formos Med Assoc. 2017;116:748-54.

67. Fukata M, Chen A, Klepper A, Krishnareddy S, Vamadevan AS, Thomas LS, et al. Cox-2 is regulated by Toll-like receptor-4 (TLR4) signaling: role in proliferation and apoptosis in the intestine. Gastroenterology. 2006;131:862-77.

68. Porreca E, Reale M, Di Febbo C, Di Gioacchino M, Barbacane RC, Castellani $\mathrm{ML}$, et al. Down-regulation of cyclooxygenase-2 (COX-2) by interleukin-1 receptor antagonist in human monocytes. Immunology. 1996;89:424-9.

69. Berg DJ, Zhang J, Lauricella DM, Moore SA. II-10 is a central regulator of cyclooxygenase-2 expression and prostaglandin production. J Immunol. 2001;166:2674-80.

70. Teloni R, Giannoni F, Rossi P, Nisini R, Gagliardi MC. Interleukin-4 inhibits cyclo-oxygenase-2 expression and prostaglandin $\mathrm{E}$ production by human mature dendritic cells. Immunology. 2007;120:83-9.

71. Keshavarzi Z, Khaksari M, Razmi Z, Soltani Hekmat A, Naderi V, Rostami S. The effects of cyclooxygenase inhibitors on the brain inflammatory response following traumatic brain injury in rats. Iran J Basic Med Sci. 2012;15:1102-5.

72. Anderson GD, Hauser SD, McGarity KL, Bremer ME, Isakson PC, Gregory SA. Selective inhibition of cyclooxygenase (COX)-2 reverses inflammation and expression of COX-2 and interleukin 6 in rat adjuvant arthritis. J Clin Invest. 1996;97:2672-9.

73. Kawashima M, Ogura N, Akutsu M, Ito K, Kondoh T. The anti-inflammatory effect of cyclooxygenase inhibitors in fibroblast-like synoviocytes from the human temporomandibular joint results from the suppression of PGE2 production. J Oral Pathol Med. 2013;42:499-506.
74. Vieira MJ, Perosa SR, Argaaaraz GA, Silva JA Jr, Cavalheiro EA, Graca NaffahMazzacoratti M. Indomethacin can downregulate the levels of inflammatory mediators in the hippocampus of rats submitted to pilocarpine-induced status epilepticus. Clinics. 2014;69:621-6.

75. Smith WL, DeWitt DL, Garavito RM. Cyclooxygenases: structural, cellular, and molecular biology. Annu Rev Biochem. 2000;69:145-82.

76. Zidar N, Odar K, Glavac D, Jerse M, Zupanc T, Stajer D. Cyclooxygenase in normal human tissues--is COX-1 really a constitutive isoform, and COX-2 an inducible isoform? J Cell Mol Med. 2009;13:3753-63.

77. Rouzer CA, Marnett LJ. Cyclooxygenases: structural and functional insights. J Lipid Res. 2009;50(Suppl):S29-34.

78. Yamagata K, Andreasson Kl, Kaufmann WE, Barnes CA, Worley PF. Expression of a mitogen-inducible cyclooxygenase in brain neurons: regulation by synaptic activity and glucocorticoids. Neuron. 1993;11:371-86.

79. Chen J, Marsh T, Zhang JS, Graham SH. Expression of cyclo-oxygenase 2 in rat brain following kainate treatment. Neuroreport. 1995;6:245-8.

80. Adams J, Collaço-Moraes Y, de Belleroche J. Cyclooxygenase-2 induction in cerebral cortex: an intracellular response to synaptic excitation. J Neurochem. 1996:66:6-13.

81. Marcheselli VL, Bazan NG. Sustained induction of prostaglandin endoperoxide synthase- 2 by seizures in hippocampus. Inhibition by a platelet-activating factor antagonist. J Biol Chem. 1996;271:24794-9.

82. Kawaguchi K, Hickey RW, Rose ME, Zhu L, Chen J, Graham SH. Cyclooxygenase-2 expression is induced in rat brain after kainate-induced seizures and promotes neuronal death in CA3 hippocampus. Brain Res. 2005;1050:130-7.

83. Takemiya T, Maehara M, Matsumura K, Yasuda S, Sugiura H, Yamagata K. Prostaglandin E2 produced by late induced COX-2 stimulates hippocampal neuron loss after seizure in the CA3 region. Neurosci Res. 2006;56:103-10.

84. Oliveira MS, Furian AF, Royes LF, Fighera MR, Fiorenza NG, Castelli M, et al. Cyclooxygenase-2/PGE2 pathway facilitates pentylenetetrazol-induced seizures. Epilepsy Res. 2008;79:14-21.

85. Nishihara I, Minami T, Watanabe Y, Ito S, Hayaishi O. Prostaglandin E2 stimulates glutamate release from synaptosomes of rat spinal cord. Neurosci Lett. 1995;196:57-60.

86. Sang N, Zhang J, Marcheselli V, Bazan NG, Chen C. Postsynaptically synthesized prostaglandin E2 (PGE2) modulates hippocampal synaptic transmission via a presynaptic PGE2 EP2 receptor. J Neurosci. 2005;25:9858-70.

87. Fischborn SV, Soerensen J, Potschka H. Targeting the prostaglandin E2 EP1 receptor and cyclooxygenase-2 in the amygdala kindling model in mice. Epilepsy Res. 2010;91:57-65.

88. Rojas A, Gueorguieva P, Lelutiu N, Quan Y, Shaw R, Dingledine R. The prostaglandin EP1 receptor potentiates kainate receptor activation via a protein kinase $C$ pathway and exacerbates status epilepticus. Neurobiol Dis. 2014:70:74-89.

89. Jiang J, Quan Y, Ganesh T, Pouliot WA, Dudek FE, Dingledine R. Inhibition of the prostaglandin receptor EP2 following status epilepticus reduces delayed mortality and brain inflammation. Proc Natl Acad Sci U S A. 2013;110:3591-6.

90. Rojas A, Ganesh T, Lelutiu N, Gueorguieva P, Dingledine R. Inhibition of the prostaglandin EP2 receptor is neuroprotective and accelerates functional recovery in a rat model of organophosphorus induced status epilepticus. Neuropharmacology. 2015;93:15-27.

91. Rojas A, Ganesh T, Manji Z, O'neill T, Dingledine R. Inhibition of the prostaglandin E2 receptor EP2 prevents status epilepticus-induced deficits in the novel object recognition task in rats. Neuropharmacology. 2016;110:419-30.

92. Oliveira MS, Furian AF, Rambo LM, Ribeiro LR, Royes LF, Ferreira J, et al. Modulation of pentylenetetrazol-induced seizures by prostaglandin E2 receptors. Neuroscience. 2008;152:1110-8.

93. Santos AC, Temp FR, Marafiga JR, Pillat MM, Hessel AT, Ribeiro LR, et al. EP2 receptor agonist ONO-AE1-259-01 attenuates pentylenetetrazole- and pilocarpine-induced seizures but causes hippocampal neurotoxicity. Epilepsy Behav. 2017;73:180-8.

94. Ganesh T. Prostanoid receptor EP2 as a therapeutic target. J Med Chem. 2014;57:4454-65.

95. Jiang J, Yang MS, Quan Y, Gueorguieva P, Ganesh T, Dingledine R. Therapeutic window for cyclooxygenase-2 related anti-inflammatory therapy after status epilepticus. Neurobiol Dis. 2015;76:126-36.

96. Kim DK, Jang TJ. Cyclooxygenase-2 expression and effect of celecoxib in flurothyl-induced neonatal seizure. Int J Exp Pathol. 2006;87:73-8.

97. Järvelä JT, Lopez-Picon FR, Holopainen IE. Age-dependent cyclooxygenase-2 induction and neuronal damage after status epilepticus in the postnatal rat hippocampus. Epilepsia. 2008;49:832-41. 
98. Holtman L, van Vliet EA, van Schaik R, Queiroz CM, Aronica E, Gorter JA. Effects of SC58236, a selective COX-2 inhibitor, on epileptogenesis and spontaneous seizures in a rat model for temporal lobe epilepsy. Epilepsy Res. 2009;84:56-66.

99. Desjardins P, Sauvageau A, Bouthillier A, Navarro D, Hazell AS, Rose C, et al. Induction of astrocytic cyclooxygenase-2 in epileptic patients with hippocampal sclerosis. Neurochem Int. 2003;42:299-303.

100. Weidner LD, Kannan P, Mitsios N, Kang SJ, Hall MD, Theodore WH, et al. The expression of inflammatory markers and their potential influence on efflux transporters in drug-resistant mesial temporal lobe epilepsy tissue. Epilepsia. 2018;59:1507-17.

101. Hung KL, Liang JS, Wang JS, Chen HJ, Lin LJ, Lu JF. Association of a novel GABRG2 splicing variation and a PTGS2/COX-2 single nucleotide polymorphism with Taiwanese febrile seizures. Epilepsy Res. 2017;129:1-7.

102. Zlokovic BV. The blood-brain barrier in health and chronic neurodegenerative disorders. Neuron. 2008;57:178-201.

103. Collard CD, Park KA, Montalto MC, Alapati S, Buras JA, Stahl GL, et al. Neutrophil-derived glutamate regulates vascular endothelial barrier function. J Biol Chem. 2002;277:14801-11.

104. Koenig H, Trout JJ, Goldstone AD, Lu CY. Capillary NMDA receptors regulate blood-brain barrier function and breakdown. Brain Res. 1992;588:297-303.

105. Roch C, Leroy C, Nehlig A, Namer IJ. Magnetic resonance imaging in the study of the lithium-pilocarpine model of temporal lobe epilepsy in adult rats. Epilepsia. 2002;43:325-35.

106. Seiffert E, Dreier JP, Ivens S, Bechmann I, Tomkins O, Heinemann U, et al. Lasting blood-brain barrier disruption induces epileptic focus in the rat somatosensory cortex. J Neurosci. 2004;24:7829-36.

107. van Vliet EA, da Costa AS, Redeker S, van Schaik R, Aronica E, Gorter JA. Blood-brain barrier leakage may lead to progression of temporal lobe epilepsy. Brain. 2007;130:521-34.

108. Marchi N, Angelov L, Masaryk T, Fazio V, Granata T, Hernandez N, et al. Seizure-promoting effect of blood-brain barrier disruption. Epilepsia. 2007; 48:732-42.

109. Tomkins O, Shelef I, Kaizerman I, Eliushin A, Afawi Z, Misk A, et al. Bloodbrain barrier disruption in post-traumatic epilepsy. J Neurol Neurosurg Psychiatry. 2008:79:774-7.

110. Marchi N, Granata T, Ghosh C, Janigro D. Blood-brain barrier dysfunction and epilepsy: pathophysiologic role and therapeutic approaches. Epilepsia. 2012;53:1877-86.

111. Warren MS, Zerangue N, Woodford K, Roberts LM, Tate EH, Feng B, et al. Comparative gene expression profiles of $A B C$ transporters in brain microvessel endothelial cells and brain in five species including human. Pharmacol Res. 2009:59:404-13.

112. Rizzi M, Caccia S, Guiso G, Richichi C, Gorter JA, Aronica E, et al. Limbic seizures induce P-glycoprotein in rodent brain: functional implications for pharmacoresistance. J Neurosci. 2002;22:5833-9.

113. Seegers $U$, Potschka $H$, Löscher W. Expression of the multidrug transporter P-glycoprotein in brain capillary endothelial cells and brain parenchyma of amygdala-kindled rats. Epilepsia. 2002;43:675-84.

114. van Vliet E, Aronica E, Redeker S, Marchi N, Rizzi M, Vezzani A, et al. Selective and persistent upregulation of mdr1b mRNA and Pglycoprotein in the parahippocampal cortex of chronic epileptic rats. Epilepsy Res. 2004;60:203-13.

115. Volk HA, Burkhardt K, Potschka H, Chen J, Becker A, Löscher W. Neuronal expression of the drug efflux transporter P-glycoprotein in the rat hippocampus after limbic seizures. Neuroscience. 2004;123:751-9.

116. Liu X, Yang Z, Yang J, Yang H. Increased P-glycoprotein expression and decreased phenobarbital distribution in the brain of pentylenetetrazole-kindled rats. Neuropharmacology. 2007;53:657-63.

117. Hartz AM, Pekcec A, Soldner EL, Zhong Y, Schlichtiger J, Bauer B. P-gp protein expression and transport activity in rodent seizure models and human epilepsy. Mol Pharm. 2017;14:999-1011.

118. Tishler DM, Weinberg KI, Hinton DR, Barbaro N, Annett GM, Raffel C. MDR1 gene expression in brain of patients with medically intractable epilepsy. Epilepsia. 1995;36:1-6.

119. Sisodiya SM, Lin WR, Harding BN, Squier MV, Thom M. Drug resistance in epilepsy: expression of drug resistance proteins in common causes of refractory epilepsy. Brain. 2002;125:22-31.

120. Liu JY, Thom M, Catarino CB, Martinian L, Figarella-Branger D, Bartolomei F, et al. Neuropathology of the blood-brain barrier and pharmaco-resistance in human epilepsy. Brain. 2012;135:3115-33.
121. Feldmann M, Asselin MC, Liu J, Wang S, McMahon A, Anton-Rodriguez J, et al. P-glycoprotein expression and function in patients with temporal lobe epilepsy: a case-control study. Lancet Neurol. 2013;12:777-85.

122. Volk HA, Löscher W. Multidrug resistance in epilepsy: rats with drug-resistant seizures exhibit enhanced brain expression of P-glycoprotein compared with rats with drug-responsive seizures. Brain. 2005;128:1358-68.

123. Zhu HJ, Liu GQ. Glutamate up-regulates P-glycoprotein expression in rat brain microvessel endothelial cells by an NMDA receptor-mediated mechanism. Life Sci. 2004;75:1313-22

124. Bauer B, Hartz AM, Pekcec A, Toellner K, Miller DS, Potschka H. Seizure-induced up-regulation of P-glycoprotein at the blood-brain barrier through glutamate and cyclooxygenase-2 signaling. Mol Pharmacol. 2008;73:1444-53.

125. Avemary J, Salvamoser JD, Peraud A, Rémi J, Noachtar S, Fricker G, et al. Dynamic regulation of P-glycoprotein in human brain capillaries. Mol Pharm. 2013;10:3333-41.

126. Zibell G, Unkrüer B, Pekcec A, Hartz AM, Bauer B, Miller DS, et al. Prevention of seizure-induced up-regulation of endothelial P-glycoprotein by COX-2 inhibition. Neuropharmacology. 2009;56:849-55.

127. van Vliet EA, Zibell G, Pekcec A, Schlichtiger J, Edelbroek PM, Holtman L, et al. COX-2 inhibition controls P-glycoprotein expression and promotes brain delivery of phenytoin in chronic epileptic rats. Neuropharmacology. 2010;58:404-12.

128. Pekcec A, Unkrüer B, Schlichtiger J, Soerensen J, Hartz AM, Bauer B, et al. Targeting prostaglandin E2 EP1 receptors prevents seizureassociated P-glycoprotein up-regulation. J Pharmacol Exp Ther. 2009; 330:939-47.

129. Rojas A, Jiang J, Ganesh T, Yang MS, Lelutiu N, Gueorguieva P, et al. Cyclooxygenase-2 in epilepsy. Epilepsia. 2014;55:17-25.

130. Elkhayat HA, Aly RH, Elagouza IA, El-Kabarity RH, Galal YI. Role of Pglycoprotein inhibitors in children with drug-resistant epilepsy. Acta Neurol Scand. 2017;136:639-44.

131. Schlichtiger J, Pekcec A, Bartmann H, Winter P, Fuest C, Soerensen J, et al. Celecoxib treatment restores pharmacosensitivity in a rat model of pharmacoresistant epilepsy. Br J Pharmacol. 2010;160:1062-71.

132. Gobbo OL, O'Mara SM. Post-treatment, but not pre-treatment, with the selective cyclooxygenase-2 inhibitor celecoxib markedly enhances functional recovery from kainic acid-induced neurodegeneration. Neuroscience. 2004;125:317-27.

133. Baik EJ, Kim EJ, Lee SH, Moon C. Cyclooxygenase-2 selective inhibitors aggravate kainic acid induced seizure and neuronal cell death in the hippocampus. Brain Res. 1999;843:118-29.

134. Kim HJ, Chung Jl, Lee SH, Jung YS, Moon CH, Baik EJ. Involvement of endogenous prostaglandin F2alpha on kainic acid-induced seizure activity through FP receptor: the mechanism of proconvulsant effects of COX-2 inhibitors. Brain Res. 2008;1193:153-61.

135. Jung KH, Chu K, Lee ST, Kim J, Sinn DI, Kim JM, et al. Cyclooxygenase-2 inhibitor, celecoxib, inhibits the altered hippocampal neurogenesis with attenuation of spontaneous recurrent seizures following pilocarpineinduced status epilepticus. Neurobiol Dis. 2006;23:237-46.

136. Citraro R, Leo A, Marra R, De Sarro G, Russo E. Antiepileptogenic effects of the selective COX-2 inhibitor etoricoxib, on the development of spontaneous absence seizures in WAG/Rij rats. Brain Res Bull. 2015;113:1-7.

137. Katyal J, Kumar H, Gupta YK. Anticonvulsant activity of the cyclooxygenase-2 (COX-2) inhibitor etoricoxib in pentylenetetrazole-kindled rats is associated with memory impairment. Epilepsy Behav. 2015:44:98-103.

138. Dhir A, Naidu PS, Kulkarni SK. Effect of cyclooxygenase-2 (COX-2) inhibitors in various animal models (bicuculline, picrotoxin, maximal electroshockinduced convulsions) of epilepsy with possible mechanism of action. Indian J Exp Biol. 2006;44:286-91.

139. Kunz T, Oliw EH. Nimesulide aggravates kainic acid-induced seizures in the rat. Pharmacol Toxicol. 2001;88:271-6.

140. Dhir A, Naidu PS, Kulkarni SK. Effect of cyclooxygenase inhibitors on pentylenetetrazol (PTZ)-induced convulsions: possible mechanism of action. Prog Neuro-Psychopharmacol Biol Psychiatry. 2006;30:1478-85.

141. Dhir A, Naidu PS, Kulkarni SK. Neuroprotective effect of nimesulide, a preferential COX-2 inhibitor, against pentylenetetrazol (PTZ)-induced chemical kindling and associated biochemical parameters in mice. Seizure. 2007;16:691-7.

142. Trandafir CC, Pouliot WA, Dudek FE, Ekstrand JJ. Co-administration of subtherapeutic diazepam enhances neuroprotective effect of COX-2 inhibitor, NS-398, after lithium pilocarpine-induced status epilepticus. Neuroscience. 2015;284:601-10. 
143. Polascheck N, Bankstahl M, Löscher W. The COX-2 inhibitor parecoxib is neuroprotective but not antiepileptogenic in the pilocarpine model of temporal lobe epilepsy. Exp Neurol. 2010;224:219-33.

144. Kunz T, Oliw EH. The selective cyclooxygenase-2 inhibitor rofecoxib reduces kainate-induced cell death in the rat hippocampus. Eur J Neurosci. 2001;13:569-75.

145. Akula KK, Dhir A, Kulkarni SK. Rofecoxib, a selective cyclooxygenase-2 (COX-2) inhibitor increases pentylenetetrazol seizure threshold in mice: possible involvement of adenosinergic mechanism. Epilepsy Res. 2008;78:60-70

146. Claycomb RJ, Hewett SJ, Hewett JA. Prophylactic, prandial rofecoxib treatment lacks efficacy against acute PTZ-induced seizure generation and kindling acquisition. Epilepsia. 2011;52:273-83.

147. Holtman L, van Vliet EA, Edelbroek PM, Aronica E, Gorter JA. Cox-2 inhibition can lead to adverse effects in a rat model for temporal lobe epilepsy. Epilepsy Res. 2010;91:49-56.

148. Kaminski R, Kozicka M, Parada-turska J, Dziki M, Kleinrok Z, Turski WA, et al. Effect of non-steroidal anti-inflammatory drugs on the anticonvulsive activity of valproate and diphenylhydantoin against maximal electroshockinduced seizures in mice. Pharmacol Res. 1998;37:375-81.

149. Ma L, Cui XL, Wang Y, Li XW, Yang F, Wei D, et al. Aspirin attenuates spontaneous recurrent seizures and inhibits hippocampal neuronal loss, mossy fiber sprouting and aberrant neurogenesis following pilocarpine-induced status epilepticus in rats. Brain Res. 2012;1469:103-13.

150. Zhu K, Hu M, Yuan B, Liu JX, Liu Y. Aspirin attenuates spontaneous recurrent seizures in the chronically epileptic mice. Neurol Res. 2017;39:744-57.

151. Jeong KH, Kim JY, Choi YS, Lee MY, Kim SY. Influence of aspirin on pilocarpineinduced epilepsy in mice. Korean J Physiol Pharmacol. 2013;17:15-21.

152. Lin TY, Lu CW, Wang CC, Huang SK, Wang SJ. Cyclooxygenase 2 inhibitor celecoxib inhibits glutamate release by attenuating the PGE2/EP2 pathway in rat cerebral cortex endings. J Pharmacol Exp Ther. 2014;351:134-45.

153. An Y, Belewych N, Wang $Y$, Zhang $H$, Herschman $H$, Chen Q, et al. Neuronal and nonneuronal COX-2 expression confers neurotoxic and neuroprotective phenotypes in response to excitotoxin challenge. J Neurosci Res. 2014;92:486-95.

154. Zhang C, Kwan P, Zuo Z, Baum L. The transport of antiepileptic drugs by Pglycoprotein. Adv Drug Deliv Rev. 2012;64:930-42.

155. van Vliet EA, van Schaik R, Edelbroek PM, Voskuyl RA, Redeker S, Aronica E, et al. Region-specific overexpression of P-glycoprotein at the blood-brain barrier affects brain uptake of phenytoin in epileptic rats. J Pharmacol Exp Ther. 2007:322:141-7.

156. Potschka H, Löscher W. In vivo evidence for P-glycoprotein-mediated transport of phenytoin at the blood-brain barrier of rats. Epilepsia. 2001;42: 1231-40.

157. van Vliet EA, van Schaik R, Edelbroek PM, Redeker S, Aronica E, Wadman WJ, et al. Inhibition of the multidrug transporter P-glycoprotein improves seizure control in phenytoin-treated chronic epileptic rats. Epilepsia. 2006;47: $672-80$

158. Lim JA, Jung KY, Park B, Kim TJ, Jun JS, Kim KT, et al. Impact of a selective cyclooxygenase-2 inhibitor, celecoxib, on cortical excitability and electrophysiological properties of the brain in healthy volunteers: a randomized, double-blind, placebo-controlled study. PLoS One. 2019;14: e0212689.

159. van Stuijvenberg M, Derksen-Lubsen G, Steyerberg EW, Habbema JD, Moll HA. Randomized, controlled trial of ibuprofen syrup administered during febrile illnesses to prevent febrile seizure recurrences. Pediatrics. 1998;102:E51.

160. Udani V, Pujar S, Munot P, Maheshwari S, Mehta N. Natural history and magnetic resonance imaging follow-up in 9 Sturge-Weber Syndrome patients and clinical correlation. J Child Neurol. 2007;22:479-83.

161. Bay MJ, Kossoff EH, Lehmann CU, Zabel TA, Comi AM. Survey of aspirin use in Sturge-Weber syndrome. J Child Neurol. 2011;26:692-702.

162. Lance El, Sreenivasan AK, Zabel TA, Kossoff EH, Comi AM. Aspirin use in Sturge-Weber syndrome: side effects and clinical outcomes. J Child Neurol. 2013:28:213-8

163. Godfred RM, Parikh MS, Haltiner AM, Caylor LM, Sepkuty JP, Doherty MJ. Does aspirin use make it harder to collect seizures during elective videoEEG telemetry? Epilepsy Behav. 2013;27:115-7.

\section{Publisher's Note}

Springer Nature remains neutral with regard to jurisdictional claims in published maps and institutional affiliations.

\section{Ready to submit your research? Choose BMC and benefit from:}

- fast, convenient online submission

- thorough peer review by experienced researchers in your field

- rapid publication on acceptance

- support for research data, including large and complex data types

- gold Open Access which fosters wider collaboration and increased citations

- maximum visibility for your research: over $100 \mathrm{M}$ website views per year

At $\mathrm{BMC}$, research is always in progress.

Learn more biomedcentral.com/submissions 